\begin{tabular}{ll}
\hline \hline MINING AND METALLURGY INSTITUTE BOR & ISSN: 2334-8836 (Štampano izdanje) \\
UDK: 622 & ISSN: 2406-1395 (Online) \\
\hline \hline
\end{tabular}

\author{
Marijana Pavlov-Kagadejev ${ }^{*}$, Radojle Radetic ${ }^{* *}$, Vladimir Despotovic $^{* * *}$

\section{IMPACT OF ADMINISTRATIVE MEASURES ON ELECTRICAL ENERGY COSTS IN COPPER PRODUCTION ${ }^{* * * * *}$}

\begin{abstract}
The Mining and Smelting Complex Bor (RTB) is one of the biggest electrical energy consumers in Serbia, with costs that exceed 3 million USD per month, or between 30 and 40 million USD per year. A complex technological process of copper production comprises mining, concentrate production (flotation), smelting and electrolytic refining. In all these stages a large amount of energy is consumed. The electricity is supplied from the power plants using 5 substations: two of them located in Bor, and the remaining three in Majdanpek. The conditions for delivery and billing of the electrical energy were defined by the contract with the supplier. The methods of billing (calculation) the electrical energy costs were changed several times in the previous 25 years. Although the consumed energy is the largest part of the overall costs, there were also some indirect costs affecting the final monthly price. It is clear that even a minor percentage decrease of costs can lead to substantial savings in the total amount. Hence, different technological and organizational activities were undertaken to reduce these costs. The paper presents primarily the effects of administrative measures on the amount of total electrical energy costs in copper production.
\end{abstract}

Keywords: Mining and metallurgy, electrical energy, active energy, reactive energy, peak load

\title{
INTRODUCTION
}

Copper production in RTB includes various technological and organizational activities in a wider geographical area [1]. In these activities, the large amounts of electrical energy are consumed [2]. For the security of power supply, the five primary transformer substations (TS) $\left(110 \mathrm{kV} / 6 \mathrm{kV}^{*}\right)$ were built; two located in Bor, and three located in Majdanpek. The total installed capacity of all power stations in RTB is close to 500 MVA. All costs (including energy and power) are calculated and billed by the electrical energy supplier at the level of consumer substations, not the individual plants that are the part of RTB. Allocation of costs within RTB organizational units - plants and factories, is carried out based on the internal measurements. Measures to reduce these costs have always been undertaken, but until late 80s and early 90s there was no systematic monitoring and control of power and energy consumption, so these measures

\footnotetext{
* Mining and Metallurgy Institute Bor, ZeleniBulevar 35, 19210 Bor, Serbia, e-mail:marijana.pavlov@irmbor.co.rs

** Serbian Transmission System, Nade Dimić 40, 19210 Bor, Serbia; e-mail: radojle.radetic@ems.rs

${ }^{* * * *}$ Technical Faculty Bor, University of Belgrade, V.J. 12, 19210 Bor, Serbia, e-mail:vdespotovic@tfbor.bg.ac.rs

**** This research was supported in part by the Ministry of Education, Science and Technological Development of the Republic of Serbia, Grant Nos. TR33037 and TR34005, within the framework of Technological Development Program
} 
were not always effective. In fact, at that time, design, construction and application of supervisory and control systems in transformer substations started, at the beginning only in TS Bor3 [3]. Later, the other transformer substations were included, as well as the individual plants in RTB. As the supervisory system enabled real-time and continuous monitoring of consumption, with the option of creating technical and financial reports with objective presentation and distribution of costs, an opportunity for reduction and optimization of these costs appeared [5]. Many concrete actions were undertaken in this period that can be classified into two main categories: technological and organizational; or combination of both. Very often they give the significant results [4, 6, 7, 8, 9, and 10].

The aim of this paper is not to present measures and activities to reduce the elec- trical energy costs, nor the effects, but the impact of numerous changes in the methods of calculation the costs in last 25 years. These changes were initiated by the electrical energy supplier and demanded different measures and strategies to reduce the costs, which will be denoted by administrative measures in further text.

The analysis provided in the paper covers the period 1991-2015. As a proof of concept, only the substation Bor 3 will be analyzed, as it was the first one with the installed monitoring and control system and provides continual data acquisition since 1990 (with the exception of 1999 , when it was ruined in bombing of Serbia and Montenegro). Also, all the metallurgical and some of the mining plants are electrically supplied from this transformer substation (see Table 1), hence the results can be easily generalized for other substations.

Table 1 The plants electrically supplied from TS Bor 3

\begin{tabular}{|c|l|c|}
\hline & Plant & TS Bor 3 cell \\
\hline 1 & Smelting Plant 100 & K9+K10 \\
\hline 2 & Smelting Plant 456 & K42+K43+K44 \\
\hline 3 & Electrolytic Refinery & K45+K46 \\
\hline 4 & Foundry & K17+K18 \\
\hline 5 & Old Air Separation Unit & K40+K47 \\
\hline 6 & Power Plant & K6+K21 \\
\hline 9 & New Smelting Plant & K15 \\
\hline 10 & Sulphuric Acid Plant & K30 \\
\hline 11 & Filtration & K2 \\
\hline 12 & Old Concentrator & K33+K34 \\
\hline 13 & New Concentrator & K27 \\
\hline 14 & Export pit & K5+K20 \\
\hline 15 & FOD & K14 \\
\hline 16 & New Sulphuric Acid Plant & K3 \\
\hline 17 & Power Plant for the Smelting Plant & \\
\hline 18 & Fibre-Reinforced Plastic (FRP) Unit & \\
\hline
\end{tabular}




\section{OVERVIEW OF CALCULATION} METHODS

It has already been noted that in the reporting period (1990 - 2015) RTB Bor purchased the electrical energy from the supliers according to the contracts that were signed each year. The contracts contained regulation the method of delivery, quantities and prices of electrical energy and power. Each of the contracts contained a price list with the specification of energy and power unit price, and some additional costs. Those additional costs were small both in absolute and in relative terms, and will not be further discussed in this paper. The electrical energy, active and reactive, as well as the tariff system, have the greatest influence on the overall costs. However, these costs will not be discussed in detail, because it would be necessary to take into account the productivity norms, which is beyond the scope of this paper. Hence, the focus of the article will be on power costs, as the second most significant factor influencing the overall costs, or to be more specific the peak load costs $[7,8]$. The peak load is the maximum average power load over a designated interval of time (15 minutes) during one month (Figure 1). It is clear that, under certain circumstances, 15 minutes of unusually high energy import, resulting from the concurrent start-up of power consumers, may drastically increase the power costs for an entire month. This can be often avoided with only a minimal technical effort, by just a few short, targeted interventions at the right point in time. The calculation of peak load costs has changed over the years, and the company had to adapt to these changes in order to reduce the costs. Each of these methods of calculation is discussed in details in further subsections.

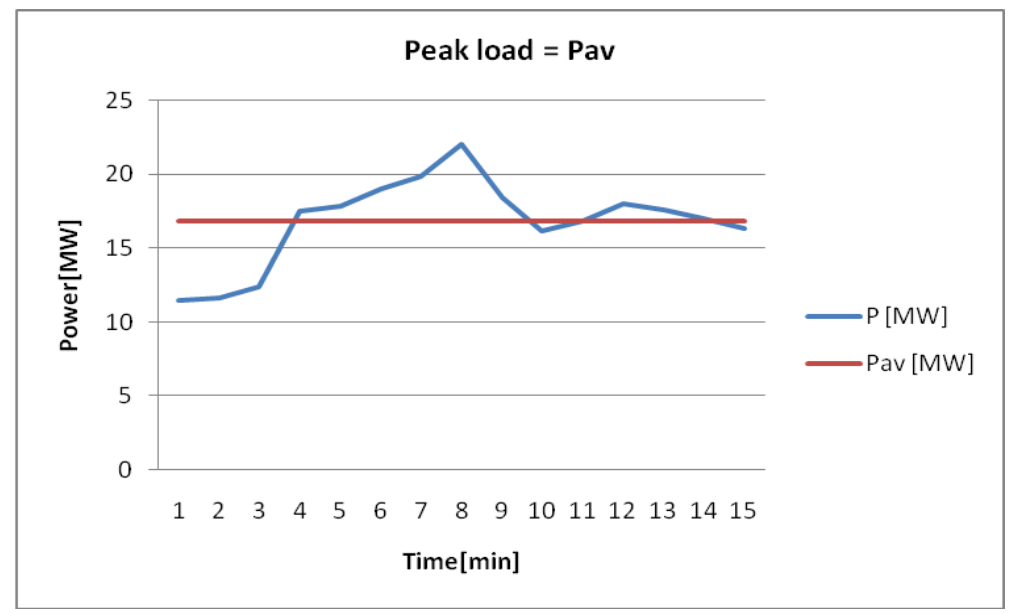

Figure 1 Peak load definition

\section{Principle of "regional peak load"}

The period 1991-2003 was characterized by the significant share of peak load costs in the total electrical energy costs, which went up to $46 \%$. Clearly, potential savings in these costs were significant, having in mind the absolute amounts of costs. 
This was also the period when a special attention was paid to development of systems, actions and algorithms for its reduction [3, 6, and 9]. However, the method of calculation the peak load costs was rather interesting. The electrical energy supplier (Elektroprivreda Srbije - EPS at that time) measured the peak load in all $110 / 6 \mathrm{kV}$ transformer substations in the Zajecar administrative district (municipalities of Zajecar, Bor, Majdanpek, Negotin, Kladovo, Knja-ževac and Boljevac) during each month. Hence, the substations that had nothing to do with RTB were also included in the calculation of peak load costs. These data were then merged to find maximum 15minute peak load values over all substations in the administrative district. The time when the maximum peak load in the whole district occurred, was further used to read the peak load in substations that supplied RTB.

This method of calculation of peak load costs was neither logical, nor fair, from the point of view of the consumer, but the supplier insisted that it was the only way to guarantee the continual supply of electrical energy to all consumers in the district. It was very difficult to optimize or reduce the costs, as the time of occurrence of peak load was not always related to production activities in RTB. It should be insisted on as less as possible engaged electrical power, and thereby the peak power was lower, anyway measured. In this way, RTB Bor achieved significant savings in 1991 [11]

The year 1991 was used as an example, as this was the year with extremely large production of cathode copper.

Table 2 Costs distribution in 1991

\begin{tabular}{|l|c|}
\hline \multicolumn{1}{|c|}{ Costs } & \\
\hline Energy (active) [USD] & 6850000 \\
\hline Peakload [USD] & 5800000 \\
\hline Total [USD] & 12650000 \\
\hline
\end{tabular}

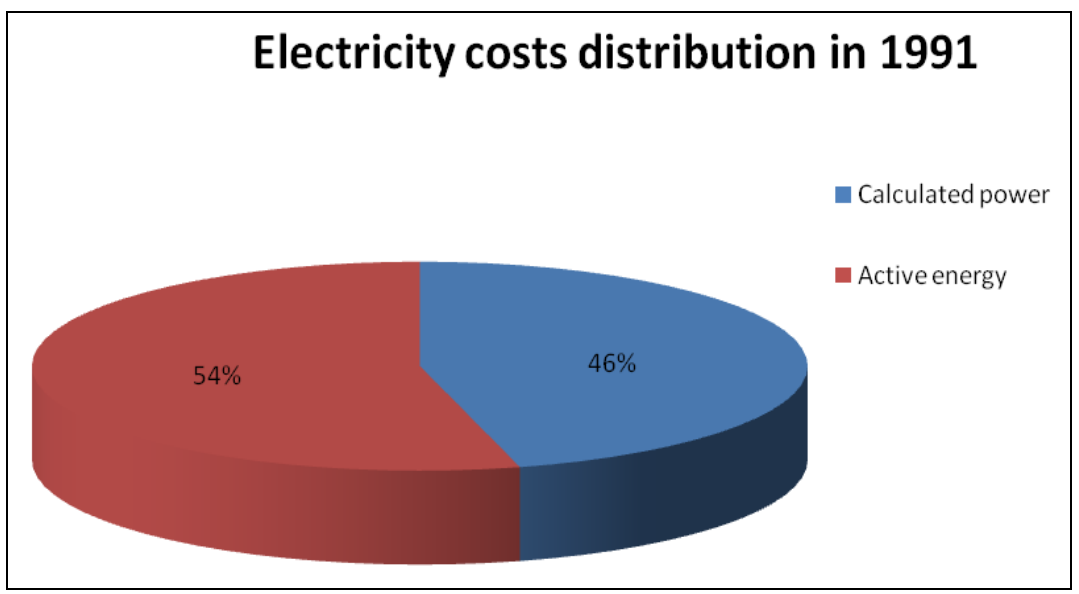

Figure 2 Costs distribution in 1991 


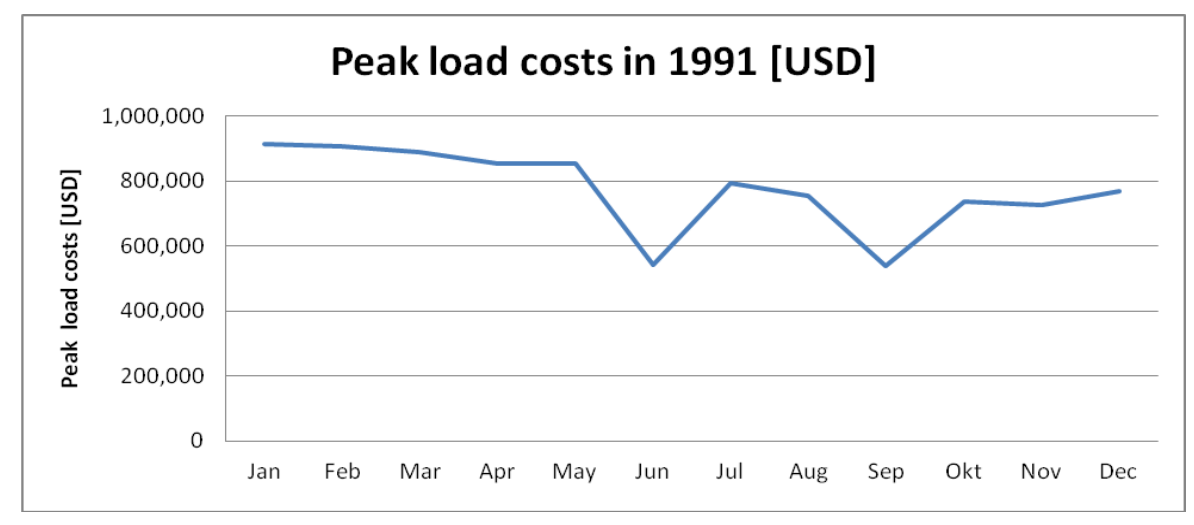

Figure 3 Measured (engaged) power in 1991

The principle of "common peak load"

From 2003 to 2008, the electrical energy supplier (Elektromreža Srbije - EMS), introduces a new method of calculation and billing the electrical energy costs. The peak load was now determined as the maximum average 15-minute sum of loads in all 5 substations that supplied RTB with electrical energy. This was a fundamental change as it included only the substations that suplied RTB. Although the RTB plants are distri-buted and very often technologically independent, it was possible, for the first time, to make organizational and procedural algorithms that would enable the optimization of power costs $[11,12]$. The dynamic plan for activation of large consumers was made, to avoid its concurrent start-up whenever it was possible, without disturbing the technological process.
In order to enable the realization of such dynamic plan, all five substations were monitored in real-time using the installed monitoring systems. Although the most optimal results would be obtained by making a centralized system that would merge the data from all substations, this was not realized due to very complex technological processes and organizational structure in RTB, so only the individual impact of every substation on reducing the peak load was assessed. However, even not optimal, these measures yielded positive results. The impact of peak load in the total costs decreased to approximately $30 \%$ (Figure 5). A typical example of annual costs for this period is shown in 2004.

Table 3 Costs distribution in 2004

\begin{tabular}{|l|r|}
\hline \multicolumn{1}{|c|}{ Costs } \\
\hline Energy (active) [USD] & 2358705 \\
\hline Peak load [USD] & 1050343 \\
\hline Other costs [USD] & 251452 \\
\hline Total [USD] & 3660501 \\
\hline
\end{tabular}




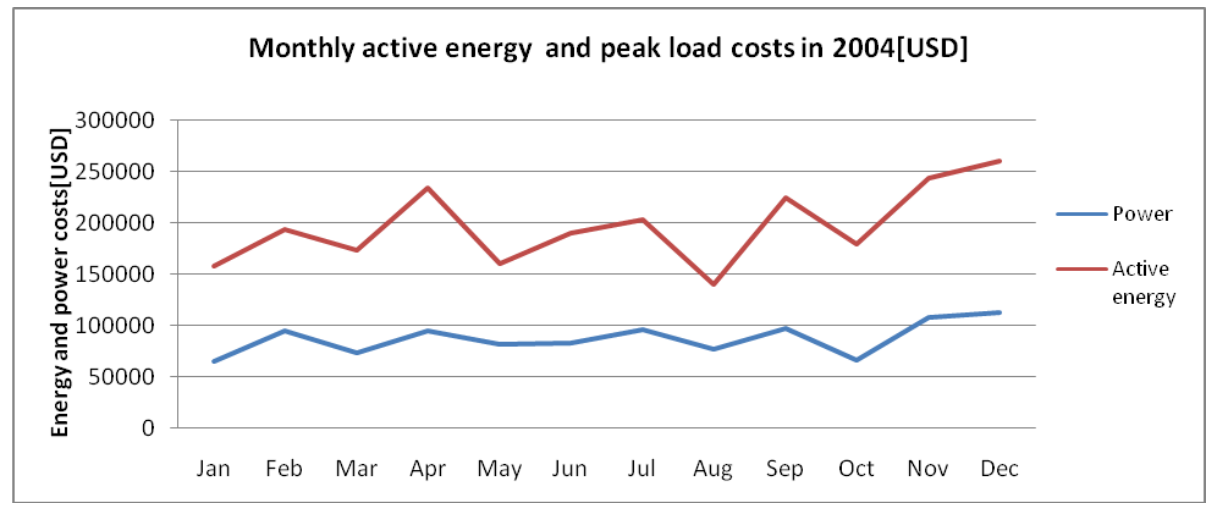

Figure 4 Consumed electrical energy and measured (engaged) power in 2004

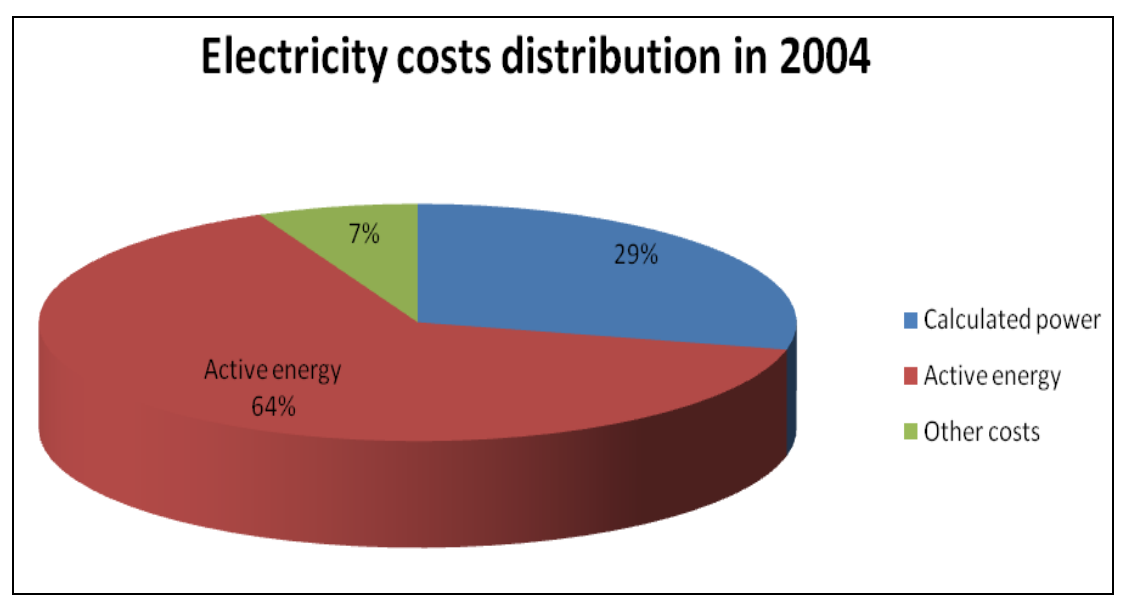

Figure 5 Costs distribution in 2004

The principle of

"individual peak load"

In the period 2008-2014, the method for calculation and billing the electrical energy costs changed again. The peak load was determined at the level of each individual substation, as its maximum average 15-minute load during one month. This was not beneficial for consumers, as the sum of maximum peak load values is always higher (or equal in the best case) then the maximal sum ("common peak

load" principle). Hence, all the actions to reduce the power costs were transferred to a lower level, a level of the single substation and plants that were supplied by this substation [14]. Technologically speaking, it was a simpler procedure, but the possibilities of savings were limited [13]. Nevertheless, the impact of power costs decreased in this way to approximately $20 \%$, as shown in Figure 6. 
Table 4 Costs distribution in 2012

\begin{tabular}{|l|r|}
\hline \multicolumn{1}{|c|}{ Costs } \\
\hline Energy (active) [USD] & 5841673 \\
\hline Peak load [USD] & 1505505 \\
\hline Other costs [USD] & 23450 \\
\hline Total [USD] & 7370488 \\
\hline
\end{tabular}

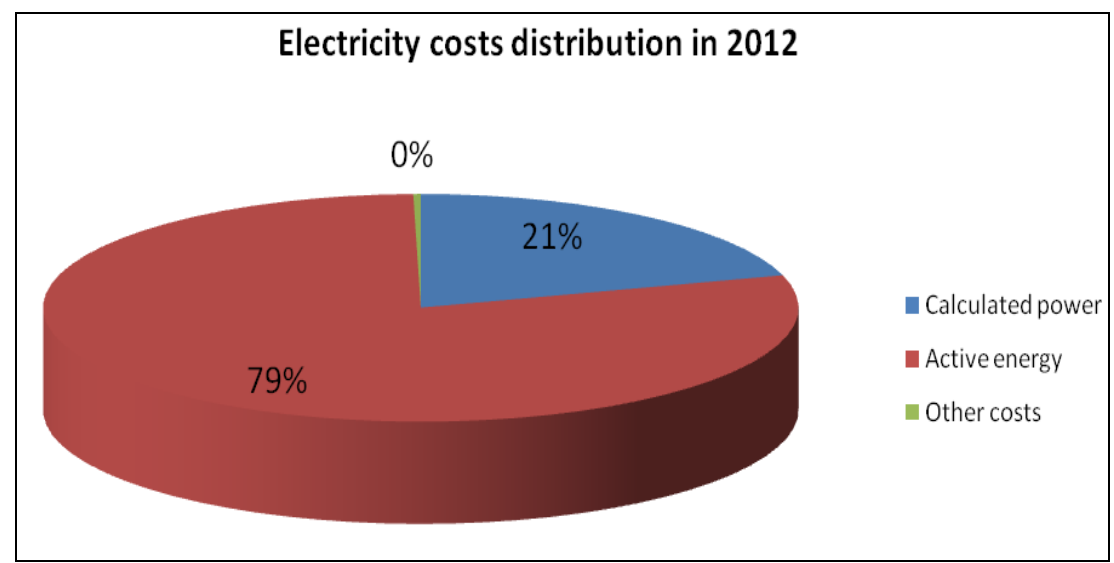

Figure 6 Costs distribution in 2012

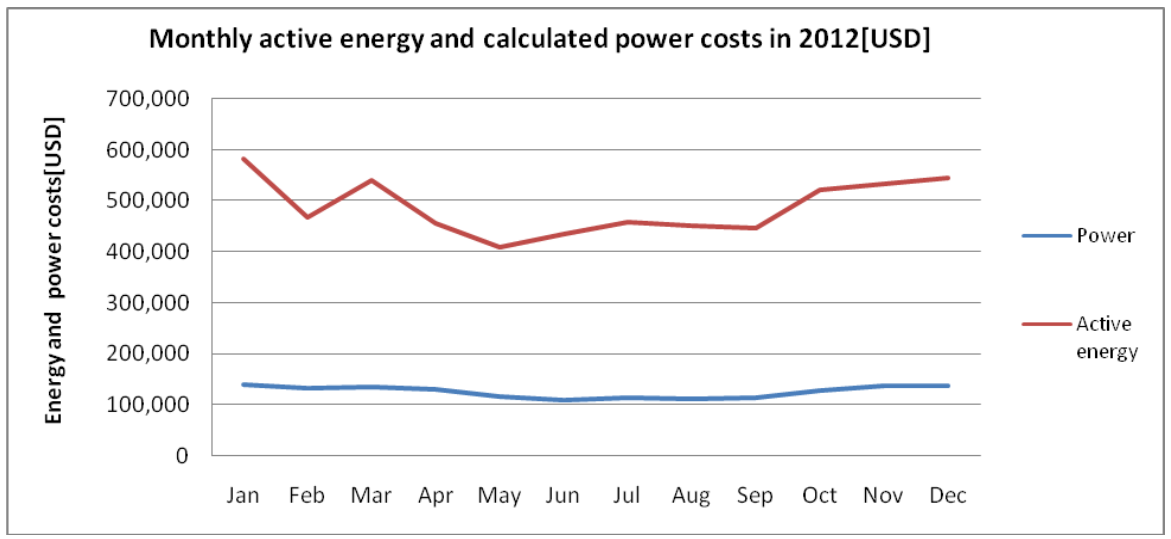

Figure 7 Costs for electrical energy and measured (engaged) power in 2012

The principle of "approved peak load"

Changing the laws and government regulations in 2014, the electrical energy market was liberalized, and EPS was no more the exclusive supplier. Also the terms of calculation and billing the electrical energy costs were negotiated with the supplier. Hence, the method of calculation has changed once more. 
Jugoistok (the part of EPS) was chosen as the supplier. The structure of costs consists of the consumed electrical energy, the approved electrical power and monthly dynamic for the whole year. Based on consumption in recent years, and production plans in the future, RTB needs to provide the plan to the supplier, which in turn defines the approved power, as the new term in the bill. Power was still measured as maximum average 15-minute load during the month. As long as this peak load is less than, or equal to the approved power, the user only pays the amount of approved power. Any excess over the approved value is called the excessive power, and it is billed at four times higher prices. This method of calculation requires a thorough analysis of electrical behavior in previous years and good planning and prediction of production in the year for which the agreement is to be made $[16,17]$. So, in addition to energy experts, it is necessary to involve the technical stuff in the individual organizational and technological units [18]. This method of calculation may be illustrated by the case of 2015, where it is clear that the share of the power costs decreased significantly using the new principle of cost calculation (only $3 \%$ ).

Table 5 Costs distribution in 2015

\begin{tabular}{|l|r|}
\hline \multicolumn{1}{|c|}{ Costs } & \\
\hline Energy (active) [USD] & 9533933 \\
\hline Peak load [USD] & 369809 \\
\hline Other costs [USD] & 2033869 \\
\hline Total [USD] & 11937611 \\
\hline
\end{tabular}

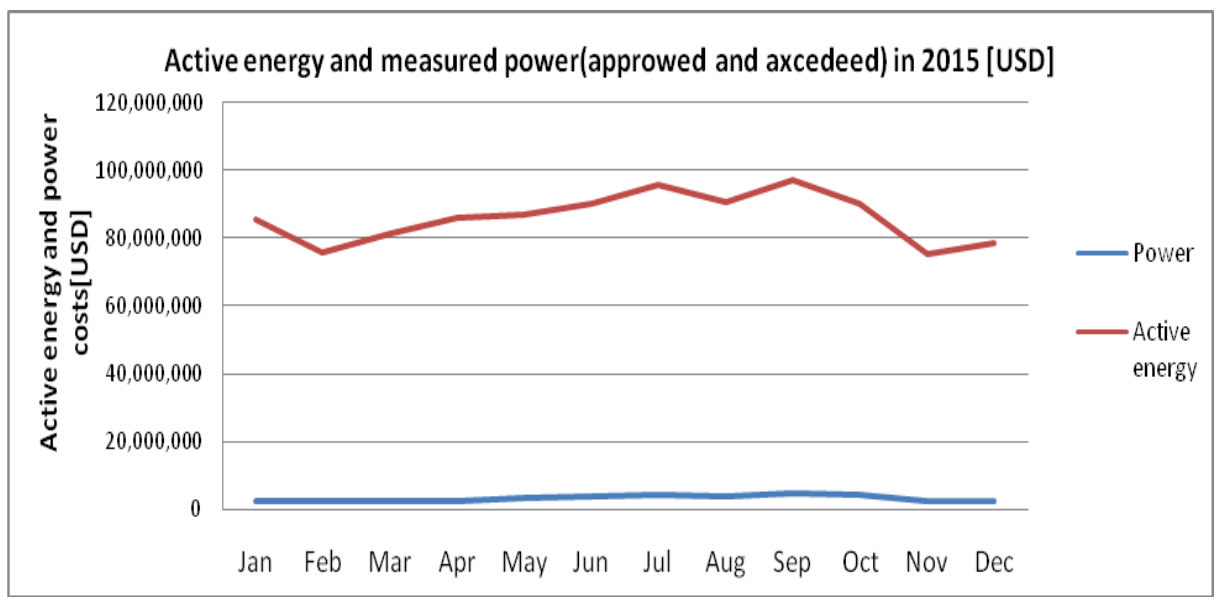

Figure 8 Monthly costs for electrical energy and measured (approved and exceeded) power in 2015 


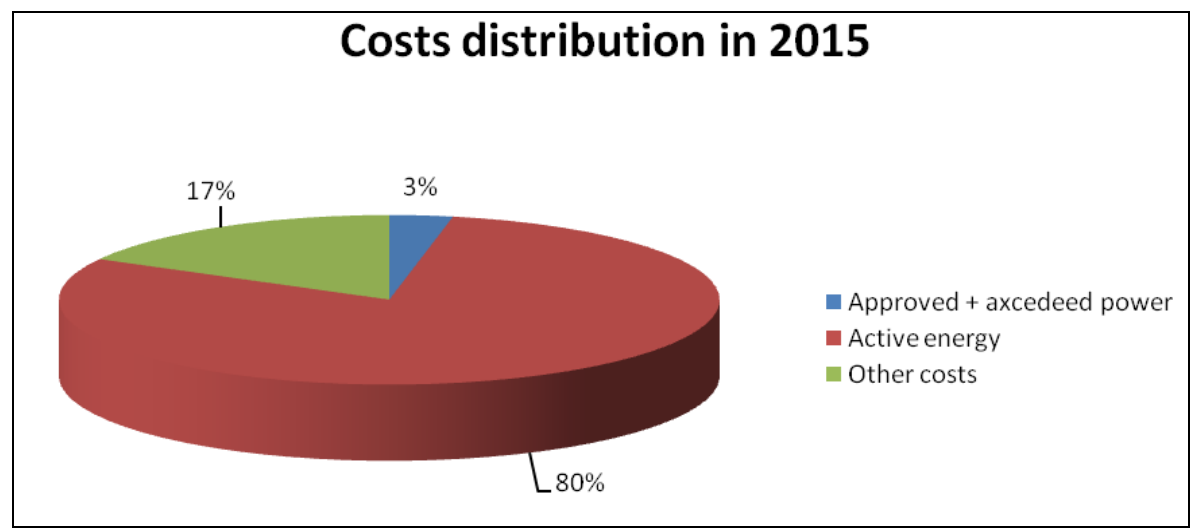

Figure 9 Costs distribution in 2012

\section{DISCUSSION}

To make a fair comparison of impacts and effects of changes in methods of calculation and billing of electrical energy, the objective measures should be used, such as: active and reactive energy, electrical power, or some administratively defined quantities, such as: excessive energy, peak load, approved power, excessive power, and the like. Active energy was the most dominant part of electrical energy costs in the whole analyzed period. Reactive energy, on the other hand, in some periods was not billed, sometimes not even measured .Note that Bor3 substation had the capacitor batteries installed (with the power of 14 MVAr); thereby the satisfactory compensation of reactive energy was achieved. However, after it was destroyed in bombing in 1999, the new one was built, but without a section for reactive power compensation. Only after years the capacitor batteries were installed, and the reactive energy was compensated.

Copper production in the observed 25year period varied from more than 100.000 tons per year in the early 1990 s to 30.000 tons in recent years. Several factors influenced the reduced production, including tech nological factors (smaller percentage of copper in the ore), political (economic sanctions during the 1990s), economic factors (drastic changes in prices on the stock market, from $1.500 \mathrm{USD} / \mathrm{t}$ in 2002 to 10.000 USD/t in 2011) etc. In order to make an objective comparison, a new quantity is defined denoted as the "average price of active energy per annum" $C_{E a}$ :

$$
C_{E a}=\frac{P_{E a}[U S D]}{E a[k W h]}
$$

where $E_{a}$ is the total active electrical energy spent over a year, and $\mathrm{P}_{E a}$ is the total annual price of this active energy denominated in USD.

In addition to active the energy, a significant part of costs was the electrical power. These costs were calculated in different ways over the analyzed period (regional peak load, common peak load, individual peak load, or the approved power and excessive power). Therefore, the concept of "average monthly price of power per annum" $C_{P}$ is introduced:

$$
C_{P}=\frac{P M C[U S D]}{A M P[k W]}
$$


Where $P M C$ represents the average monthly cost for the power over the year and $A M P$ is the average monthly power over the year (determined as the peak load or the approved peak load, depending on the analyzed period). In this way the parameters $C_{E a}$ and $C_{P}$ were introduced, that represent the unit price of energy and power, irrespective of the way of calculation. These are the two key parameters for comparison because they are dominant in the total amount of costs for each of the listed methods of calculation.

Figure 10 presents $C_{E a}$ and $C_{P}$ calculated for TS Bor 3 for all described methods of calculation

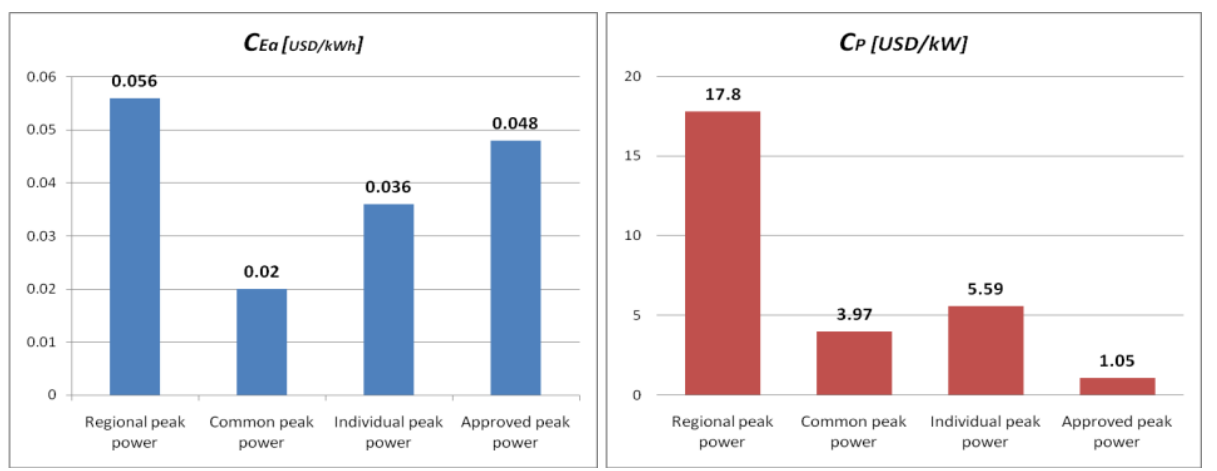

Figure 10 Energy and power unit prices for different methods

Comparison of described methods of calculation and billing the electricity costs shows that only the spent active energy represents a significant (dominant) part, independently of the used method. The other costs are allocated or categorized differently. Therefore, reducing the total consumption of active energy still has a significant effect in reducing the cost and impact on other elements (peak power, reactive power,) does not always provide equivalent savings for each of the methods. Given that the costs of reactive power are becoming bigger, it should be accessed by installing the compensation batteries in all consumer substations.

\section{CONCLUSION}

The all results presented in this paper are given for one substation (TS Bor 3) out of five that are used to supply electri-city in RTB, which has the share in the total electrical energy costs ranging from $24 \%$ to
$45 \%$ over the analyzed period. The total costs of electrical energy are approximately 3.000.000 USD per month. It is clear that savings of only $1 \%$ amounts 360.000 USD per annum. To reduce the cost of electricity various activities were undertaken in the analyzed period. In the period when 'regional' and 'common' peak load method was used, the main objective was to reduce the peak load, as the share of the peak load in the total costs was very high (up to $46 \%$ ).

The reduction and optimization of electrical energy consumption is a permanent task. This is achieved by installing the appropriate aggregates and their optimum operating regime. The current method of calculation the electrical energy costs particularly insists on careful planning the consumption, as the approved peak load is determined annually, based on the previous consumption and productivity plans. Any excess of approved power can lead to significantly increased total costs. 


\section{REFERENCES}

[1] Mitovski M., Mitovski A., Efficiency of Rational Management in Electricity Copper Metallurgy, Copper 36(2011)1, pp. 4-16 (in Serbian)

[2] Schlesinger M. E., King M .J., Sole K. C., Davenport W. G. (2011) Extractive Metallurgy of Copper. Amsterdam: Elsevier, pp. 427-439

[3] D. R. Milivojević, M. Radojković, G. Jojić Blagojevic, Dj.Šimon, S.Lalović, Distributed Microcomputer System for Monitoring and Control of Electricity Consumption in RTB Bor, Praksa No. 11-12, 1991 (ISSN 0351'675X)

[4] J. Petrović, D. Grubišić, D. R. Milivojević, M. Radojković, G. Jojić Blagojević, Dj. Šimon, S. Lalović, Effects of Operation System for Control the Consumption of Electricity in the Basin Bor in 1991, XVIII International Conference on Mining and Metallurgy, D.Milanovac, 1992

[5] G. Jojić, D. Milivojević, M. Radojković, V. Tasić, S. Lalović, Microcomputer System for Control the Consumption of Electricity in the Substations, Paper announced at the Conference ENYU99, Zlatibor, 9 - 13 March, 1999 (in Serbian)

[6] Milivojevic D. R., Jojic Blagojevic G., Radojkovic M., Lalovic S., Tasic V., (1999), Application the System for Impact on Reducing the Peak Power and Spent Electricity in RTB Bor (Possibilities and Some of Defects Realized in Practice), Energy, Economy, Ecology, 4(I), 199 (in Serbian)

[7] V. Tasić, D. Karabašević, G. Jojić, D. Milivojević: Monitoring the Consumption of Electrical Energy in TS Bor 3, Symposium YUINFO'2004, Kopaonik 9 - 13 March, 2004 (in Serbian)
[8] V. Tasić, D. R. Milivojević, D. Karabašević, V. Despotović, Z. Eskić, Monitoring - Control System in the Power Plant TIR Bor, Conference ETRAN 2005, Budva, 6-10 June, 2005 (in Serbian)

[9] D. R. Milivojević, V. Tasić, V. Despotović, A. Ignjatović, An Example of Influence on Reduction of Electrical Energy Costs, Proceedings of XLI International Scientific Conference on Information, Communication and Energy Systems and Technologies ICEST 2006, 29 June - 1 July, 2006, Sofia, Bulgaria

[10] V. Despotović, V. Tasić, D. R. Milivojević, A. Ignjatović, Power Consumption Control System in Copper Tubes Factory - Majdanpek, Proceedings of the XLI International Scientific Conference on Information, Communication and Energy Systems and Technologies ICEST 2006, 29 June - 1 July 7, 2006, Sofia, Bulgaria

[11] M. Pavlov, D. R. Milivojević, V. Tasić, V. Despotović, Distributed Control System Applied in Copper Metallurgy, Proceedings of 41. International October Conference on Mining and Metallurgy, 2009, Kladovo, Serbia

[12] D. R. Milivojevic: Experience in Reduction the Electricity Costs for Large Consumers (RTB Bor), Bakar No. 2, Vol.27 (2002), YU ISSN 03510212 [UDC 669.3] (in Serbian)

[13] V. Tasić, D. R. Milivojević, M. Pavlov, V. Despotović, Reducing the Costs of Electricity in the Copper Mining and Smelting Complex RTB Bor (Serbia) by Using of the Distributed Control System, 33 ${ }^{\text {rd }}$ International Convention on Information and Communication Techology, Electro- 
nics and Microelectronics MIPRO 2010, Opatija, May 2010, Proceedings (ISBN: 978-1-4244-7763-0)

[14] M. Pavlov, V. Despotovic, D. R. Milivojevic, V. Tasic, D. Brodic, Overview of Electrical Energy Costs in Metallurgical Plants of Copper Mining and Smelting Complex Bor, 43 ${ }^{\text {rd }}$ International October Conference, Kladovo, Octobar 12-15, 2011, Proceedings (ISBN: 978-86-80987-87-3), COBISS. (SR-ID 186644236)

[15] Methodology of Determining the Price to the Access System of Electric Energy Distribution, Chapte XIII, Official Gazette of RS Nos. 105/12 ... 65/15), (in Serbian)

[16] V. Tasic. D. R. Milivojevic, M. Pavlov, V. Despotovic, D. Brodic, Microcontroller Based Systems for Peak Load Reduction, Proceedings of
Jubilee $35^{\text {rd }}$ International Convention on Information and Communication Technology, Electronics and Microelectronics MIPRO 2012, Opatija 2012, (ISSN: 1847-3946)

[17] V. Tasić, V. Despotović, D. Brodić, M. Pavlov, D. R. Milivojević, Twenty Years of Monitoring and Control of Electricity Consumption in RTB Bor, Serbia, Proceedings of $36^{\text {rd }}$ International Convention on Information and Communication Techology, Electronics and Microelectronics MIPRO 2013, Opatija 2013, (ISSN: 18473946)

[18] M. Pavlov Kagadejev, V. Tasić, D. Brodić, D. R. Milivojević, The Analysis of Electro-Energetic System Elements in Majdanpek Copper Mine, $45^{\text {rd }}$ International October Conference, Bor Lake, October 16-19, 2013. 